\title{
Soil Adsorption and Its Mechanism of the Fungicide Mepanipyrim
}

\author{
Yutaro NAGAI, Kayoko ShImbA, Yoshio YUSA, ${ }^{*}$ and Akira YAGI \\ Life Science Research Institute, Kumiai Chemical Industry Co., Ltd., Tamari, Kakegawa 436-0011, Japan \\ *present address ; Ecopro Research Co., Ltd., Shibukawa, Shimizu 424-0053, Japan
}

(Received December 14, 1998; Accepted May 6, 1999)

\begin{abstract}
Soil adsorption of mepanipyrim labeled with ${ }^{14} \mathrm{C}$ was investigated using a batch equilibrium method, and isotherms were calculated by the Freundlich equation for five different Japanese soils collected from the upland fields. The Freundlich equation described mepanipyrim adsorption adequately. Adsorption coefficients $\left(K_{\mathrm{f}}\right)$ ranged from 12.9 to 427 , and normalized $K_{\mathrm{f}}$ based on the soil organic carbon content $\left(K_{\mathrm{f}, \mathrm{cc}}\right)$ from 1090 to 5210 . The values of $1 / n$ were smaller than unity for all soils tested. Desorption of mepanipyrim was hysteretic. Soil adsorption of mepanipyrim was $\mathrm{pH}$ dependent, showing the maximum adsorption at a $\mathrm{pH}$ value in the vicinity of its $\mathrm{p} K$ a 2.9. It is considered that the ionic bond between protonated mepanipyrim and the minus charge on soil colloid contributes to this $\mathrm{pH}$ effect. After decomposition of the soil organic matter with $\mathrm{H}_{2} \mathrm{O}_{2}, K_{\mathrm{f}}$ values decreased for all soils tested. Adsorption of mepanipyrim on the $\mathrm{H}_{2} \mathrm{O}_{2}$ treated soils increased with the decreasing $\mathrm{pH}$ in the $\mathrm{pH}$ range above the $\mathrm{p} K \mathrm{a}$ value.
\end{abstract}

Key words: pesticide, mepanipyrim, adsorption, soil $\mathrm{pH}$.

\section{INTRODUCTION}

Mepanipyrim, $N$-(4-methyl-6-prop-1-ynylpyrimidin-2-yl)aniline is a fungicide developed by Kumiai Chemical Industry Co., Ltd. and Ihara Chemical Industry Co., Ltd. ${ }^{1)}$ Mepanipyrim has a good disease control activity for gray mould, scab, and brown rot and has been used on several horticultural crops and fruit trees. ${ }^{2)}$

Soil adsorption governs the environmental fate of agrochemicals by controlling directly the mobility, the leaching potential, and the availability for chemical and biological degradation in soils. Therefore the information on soil adsorption of mepanipyrim is essential for predicting its environmental fate and behavior. Soil adsorption of weak bases like atrazine is known to be $\mathrm{pH}$ dependent. ${ }^{3-5)}$ Mepanipyrim is also a weak base having the $\mathrm{p} K \mathrm{a}$ of 2.9 (private data determined by the spectrophotometric method in K-I Chemical Research Institute Co., Ltd.) and it was expected that its soil adsorption was influenced by $\mathrm{pH}$. In this report we deal with the adsorption characteristics of mepanipyrim on five Japanese soils, the effect of $\mathrm{pH}$ on the soil adsorption, and the adsorption on soils treated with $\mathrm{H}_{2} \mathrm{O}_{2}$ to oxidize soil organic matters to clarify the role of soil organic matter and mineral constituents.

\section{MATERIALS AND METHODS}

1. ${ }^{14} \mathrm{C}$-Labeled Compound and Authentic Compound The structural formula of mepanipyrim is shown in Fig. 1. Mepanipyrim labeled with ${ }^{14} \mathrm{C}$ uniformly on its benzene ring was synthesized by Daiichi Pure Chemicals Co., Ltd. It had a specific activity of $808 \mathrm{MBq} / \mathrm{mmol}$ and a radiochemical purity of $96.2 \%$. The authentic compound of non-labeled mepanipyrim was synthesized by K-I Chemical Research Institute Co., Ltd. The water solubility of mepanipyrim is $3.10 \mu \mathrm{g} / \mathrm{ml}$ at $25^{\circ} \mathrm{C}$. To prevent precipitation of mepanipyrim, the maximum concentration used was less than half of its water solubility.

\section{Soils}

Five Japanese soils collected from the plow layers of the upland fields in Nagano (Nagano-pref.), Kikugawa (Shizuoka-pref.), Ushiku (Ibaraki-pref.), Koriyama (Fukushima-pref.), and Kume (Okayama-pref.) were passed through a $2 \mathrm{~mm}$ screen prior to use. The physicochemical properties of the test soils are shown in Table 1.

\section{Preparation of $\mathrm{H}_{2} \mathrm{O}_{2}$ Treated Soils}

The five soils were heated at $80^{\circ} \mathrm{C}$ with $6 \% \mathrm{H}_{2} \mathrm{O}_{2}$ solution being added with $6 \% \mathrm{H}_{2} \mathrm{O}_{2}$ solution repeatedly until 
<smiles>CC#Cc1cc(C)nc(Nc2ccccc2)n1</smiles>

Fig. 1 Structural formula of mepanipyrim.

drastic bubble generation ceased. The soils were rinsed with distilled water well and air-dried.

Organic carbon contents of the $\mathrm{H}_{2} \mathrm{O}_{2}$ treated soils are shown in Table 1. Though the $\mathrm{H}_{2} \mathrm{O}_{2}$ treatment reduced the carbon contents effectively for all soils used, Nagano and Ushiku $\mathrm{H}_{2} \mathrm{O}_{2}$ treated soils still had 0.82 and $0.58 \%$ of organic carbon, respectively.

\section{Equilibration Time and ${ }^{14} \mathrm{C}$-Material Balance}

A preliminary study showed that the soil adsorption of mepanipyrim reached the equilibrium within $72 \mathrm{hr}$ for all soils tested (data are not shown here).

The $72 \mathrm{hr}$ sample of each soil in the preliminary study mentioned above and the $72 \mathrm{hr}$ sample of each $\mathrm{H}_{2} \mathrm{O}_{2}$ treated soil from adsorption studies, which were centrifuged, were used for the determination of ${ }^{14} \mathrm{C}$ material balance in the test systems. The supernatant and acetone extract from the precipitate were extracted with dichloromethane, respectively, and each dichloromethane extract was analyzed by co-chromatography using a silica gel TLC plate. The non-extractable ${ }^{14} \mathrm{C}$ remaining after the acetone extraction of each precipitate was oxidized using a Packard Sample Oxidizer and radioassayed.

The distribution of ${ }^{14} \mathrm{C}$ and ${ }^{14} \mathrm{C}$-mepanipyrim were shown in Table 2. Since the recoveries of ${ }^{14} \mathrm{C}$ mepanipyrim from the $72 \mathrm{hr}$ samples were greater than $87 \%$, it was considered that the degradation of mepanipyrim in the soil and water systems was slight after $72 \mathrm{hr}$ shaking. Accordingly, $72 \mathrm{hr}$ shaking time was employed for all studies reported in this report.

\section{Adsorption}

The adsorption studies were conducted using a batch equilibrium method. All treatments were duplicated.

Table 1 Physicochemical properties of the test soils.

\begin{tabular}{|c|c|c|c|c|c|c|c|c|c|c|c|c|}
\hline \multirow{2}{*}{\multicolumn{2}{|c|}{$\begin{array}{l}\text { Soil (Prefecture } \\
\text { of sampling) }\end{array}$}} & \multicolumn{3}{|c|}{ Particle size distribution(\%) } & \multirow{3}{*}{$\begin{array}{c}\begin{array}{c}\text { Soil }{ }^{\mathrm{a})} \\
\text { texture }\end{array} \\
\mathrm{L}\end{array}$} & \multirow{3}{*}{$\begin{array}{c}\begin{array}{c}\text { Organic carbon } \\
\text { content }^{\mathrm{b})}(\%)\end{array} \\
12.5(0.82)\end{array}$} & \multicolumn{2}{|c|}{$\mathrm{pH}$} & \multirow{3}{*}{$\begin{array}{c}\text { CEC } \\
\begin{array}{c}\text { (me/100 g } \\
\text { dry soil) }\end{array} \\
47.5\end{array}$} & \multirow{2}{*}{\multicolumn{3}{|c|}{$\begin{array}{l}\text { Main clay } \\
\text { mineral }^{c)}\end{array}$}} \\
\hline & & \multirow{2}{*}{\begin{tabular}{|l} 
Sand \\
54.5
\end{tabular}} & \multirow{2}{*}{\begin{tabular}{|l} 
Silt \\
35.6
\end{tabular}} & \multirow{2}{*}{$\begin{array}{c}\text { Clay } \\
9.9\end{array}$} & & & \multirow{2}{*}{$\begin{array}{r}\mathrm{H}_{2} \mathrm{O} \\
4.7\end{array}$} & \multirow{2}{*}{$\frac{\mathrm{KCl}}{4.2}$} & & & & \\
\hline Nagano & (Nagano) & & & & & & & & & $\mathrm{V}$ & $\mathrm{K}$ & A \\
\hline Kikugawa & (Shizuoka) & 49.5 & 29.2 & 21.4 & $\mathrm{CL}$ & $0.43(0.11)$ & 5.1 & 3.9 & 9.6 & K & I & \\
\hline Ushiku & (Ibaraki) & 42.9 & 31.4 & 25.8 & $\mathrm{LiC}$ & $3.26(0.58)$ & 7.2 & 6.2 & 25.1 & A & & \\
\hline Koriyama & (Fukushima) & 53.4 & 22.8 & 23.8 & CL & $1.08(0.18)$ & 7.6 & 6.7 & 13.5 & K & $\mathrm{V}$ & \\
\hline Kume & (Okayama) & 60.5 & 17.5 & 22.0 & SCL & $0.79(0.09)$ & 5.2 & 3.7 & 6.3 & $\mathrm{H}$ & & \\
\hline
\end{tabular}

a) L :loam; CL: clay loam; LiC: light clay; SCL: sandy clay loam. b) Numbers in parenthesis are the organic carbon content after $\mathrm{H}_{2} \mathrm{O}_{2}$ treatment. c) A: allophane; $\mathrm{H}$ : halloysite; I: illite; $\mathrm{K}$ : kaolinite; V: vermiculite. Particle size distribution and soil texture were determined by the method of International Society of Soil Science.

Table 2 Distributions of ${ }^{14} \mathrm{C}$ and ${ }^{14} \mathrm{C}$-mepanipyrim in the soil and $\mathrm{H}_{2} \mathrm{O}_{2}$ treated samples shaken for $72 \mathrm{hr}$.

\begin{tabular}{|c|c|c|c|c|c|c|c|c|c|c|}
\hline \multirow{4}{*}{ Fraction and compeund } & \multicolumn{10}{|c|}{ Percentage to applied } \\
\hline & \multicolumn{10}{|c|}{ Soil $^{\text {a) }}$} \\
\hline & \multicolumn{2}{|c|}{ Nagano } & \multicolumn{2}{|c|}{ Kikugawa } & \multicolumn{2}{|c|}{ Ushiku } & \multicolumn{2}{|c|}{ Koriyama } & \multicolumn{2}{|c|}{ Kume } \\
\hline & Original & $\mathrm{H}_{2} \mathrm{O}_{2}$ & Original & $\mathrm{H}_{2} \mathrm{O}_{2}$ & Original & $\mathrm{H}_{2} \mathrm{O}_{2}$ & Original & $\mathrm{H}_{2} \mathrm{O}_{2}$ & Original & $\mathrm{H}_{2} \mathrm{O}_{2}$ \\
\hline \multicolumn{11}{|l|}{ Supernatant } \\
\hline Mepanipyrim & 0.5 & 9.6 & 8.6 & 27. 6 & 8.3 & 42.0 & 15.3 & 36.5 & 17.1 & 79.5 \\
\hline Others $^{\mathrm{b})}$ & 0.2 & 0.4 & 0.7 & 0.2 & 0.6 & 0.6 & 2.2 & 0.4 & 2.0 & 0.7 \\
\hline \multicolumn{11}{|l|}{ Precipitate } \\
\hline Mepanipyrim & 86.5 & 84.5 & 89.7 & 69.8 & 80.3 & 58.1 & 74.3 & 58.2 & 72.0 & 19.4 \\
\hline Others $^{\text {b) }}$ & 3.0 & 0.9 & 2.5 & 4.2 & 1.8 & 0.6 & 2.7 & 0.7 & 2.8 & 0.4 \\
\hline Non-extractable ${ }^{14} \mathrm{C}$ & 10.4 & 4.7 & 4.0 & 1.0 & 7.4 & 1.5 & 14.9 & 2.5 & 5.5 & 0.9 \\
\hline Recovery of mepanipyrim & 87.0 & 94.1 & 98.3 & 97.4 & 88.6 & 100.1 & 89.6 & 94.7 & 89.1 & 98.9 \\
\hline Recovery of ${ }^{14} \mathrm{C}$ & 100.6 & 100.1 & 105.5 & 102.8 & 98.4 & 102.8 & 109.4 & 98.3 & 99.4 & 100.9 \\
\hline
\end{tabular}

a) The left column of each soil shows the values for the original soil and the right column the values for the $\mathrm{H}_{2} \mathrm{O}_{2}$ treated soil.

b) Others contain ${ }^{14} \mathrm{C}$ in the water layers obtained from the dichloromethane partition. 
Three mepanipyrim solutions were prepared at the concentrations of $0.0402 \mu \mathrm{g} / \mathrm{ml} ; 146 \mathrm{~Bq} / \mathrm{ml}, 0.20 \mu \mathrm{g} / \mathrm{ml}$; $728 \mathrm{~Bq} / \mathrm{ml}$, and $1.02 \mu \mathrm{g} / \mathrm{ml} ; 708 \mathrm{~Bq} / \mathrm{ml}$ by dissolving non-labeled and ${ }^{14} \mathrm{C}$-labeled mepanipyrim in $0.01 \mathrm{M}$ $\mathrm{CaCl}_{2}$. A $20 \mathrm{ml}$ aliquot of each mepanipyrim solution was added to $5 \mathrm{~g}$ of each soil (wet weight basis) in a 50-ml glass centrifuge tube. The tube was shaken gently on a reciprocal shaker at $25^{\circ} \mathrm{C}$ for $72 \mathrm{hr}$ to achieve equilibrium. Following the equilibration the suspension was centrifuged at $3000 \mathrm{rpm}(1400 \times g)$ for $15 \mathrm{~min}$. An aliquot of the supernatant was taken from each tube to determine the radioactivity by a Packard Tri-Carb 2750TR/LL liquid scintillation counter. Hereafter the same manner of shaking, centrifugation, and radioassay was employed.

For the $\mathrm{H}_{2} \mathrm{O}_{2}$ treated soils three solutions of mepanipyrim were prepared at the concentrations of 0.0816 $\mu \mathrm{g} / \mathrm{ml} ; 296 \mathrm{~Bq} / \mathrm{ml}, 0.408 \mu \mathrm{g} / \mathrm{ml} ; 1478 \mathrm{~Bq} / \mathrm{ml}$, and 2.04 $\mu \mathrm{g} / \mathrm{ml} ; 1478 \mathrm{~Bq} / \mathrm{ml}$. A $2 \mathrm{ml}$ aliquot of $0.01 \mathrm{M} \mathrm{CaCl}_{2}$ was added to $500 \mathrm{mg}$ of each $\mathrm{H}_{2} \mathrm{O}_{2}$ treated soil (air-dry weight basis) in a $10-\mathrm{ml}$ glass test tube and the test tube was shaken gently for $24 \mathrm{hr}$ to re-equilibrate the $\mathrm{H}_{2} \mathrm{O}_{2}$ treated soil with water. Then a $2 \mathrm{ml}$ aliquot of each mepanipyrim solution was added to the test tube. The sample was shaken and centrifuged, and the supernatant was radioassayed in the same manner described above.

The $\mathrm{pH}$ of the supernatant was measured for the samples of each soil and its $\mathrm{H}_{2} \mathrm{O}_{2}$ treated soil with the highest initial concentration by a $\mathrm{pH}$ meter.

\section{Desorption}

The desorption studies were conducted using the samples with the highest initial concentration in the adsorption studies. The supernatant in each centrifuge tube was replaced with the equivalent volume of $0.01 \mathrm{M}$ $\mathrm{CaCl}_{2}$. After the precipitate was dispersed by vibration, the sample was shaken and centrifuged, and the supernatant was radioassayed in the same manner described above.

\section{Effect of $p H$ on Mepanipyrim Adsorption}

The effect of $\mathrm{pH}$ on mepanipyrim adsorption was examined using mepanipyrim solutions whose acidity was controlled with $\mathrm{HCl}$ or $\mathrm{NaOH}$. All treatments were duplicated. Solutions of mepanipyrim at the concentration of $1.04 \mu \mathrm{g} / \mathrm{ml}$ containing ${ }^{14} \mathrm{C}$-mepanipyrim at 358 $\mathrm{Bq} / \mathrm{ml}$ were prepared by dissolving non-labeled and ${ }^{14} \mathrm{C}$ labeled mepanipyrim in $0.01 \mathrm{M} \mathrm{CaCl}_{2}$ made in distilled water, $0.1,0.075,0.05,0.025,0.01$, and $0.005 \mathrm{~N} \mathrm{HCl}$, and $0.01 \mathrm{~N} \mathrm{NaOH}$. Kikugawa and Koriyama soils were selected as one of the low $\mathrm{pH}$ and of high $\mathrm{pH}$ soils, respectively. Five grams of each soil (wet weight basis) and $20 \mathrm{ml}$ of each mepanipyrim solution were shaken and centrifuged, and the supernatant was radioassayed in the same manner described above.
For the $\mathrm{H}_{2} \mathrm{O}_{2}$ treated soils solutions of mepanipyrim at $2.04 \mu \mathrm{g} / \mathrm{ml}$ containing ${ }^{14} \mathrm{C}$-mepanipyrim at $1478 \mathrm{~Bq} / \mathrm{ml}$ were prepared by dissolving non-labeled and ${ }^{14} \mathrm{C}$-labeled mepanipyrim in $0.01 \mathrm{M} \mathrm{CaCl}_{2}$ made in distilled water, $0.04,0.01,0.008,0.006,0.004$, and $0.002 \mathrm{~N} \mathrm{HCl}$ and 0.004 , and $0.008 \mathrm{~N} \mathrm{NaOH}$. The solution made in distilled water were used for all soils. The $0.01 \mathrm{~N} \mathrm{HCl}$ and $0.008 \mathrm{~N} \mathrm{NaOH}$ solutions were used for Nagano $\mathrm{H}_{2} \mathrm{O}_{2}$ treated soil, 0.004 and $0.002 \mathrm{~N} \mathrm{HCl}$ and $0.004 \mathrm{~N} \mathrm{NaOH}$ solutions for Kikugawa and Kume $\mathrm{H}_{2} \mathrm{O}_{2}$ treated soils, 0.004 and $0.002 \mathrm{~N} \mathrm{HCl}$ and $0.004 \mathrm{~N} \mathrm{NaOH}$ solutions for Koriyama $\mathrm{H}_{2} \mathrm{O}_{2}$ treated soil, and 0.04 and $0.008 \mathrm{~N} \mathrm{HCl}$ and $0.004 \mathrm{~N} \mathrm{NaOH}$ for Ushiku $\mathrm{H}_{2} \mathrm{O}_{2}$ treated soil. A 2 $\mathrm{ml}$ aliquot of $0.01 \mathrm{M} \mathrm{CaCl}_{2}$ was added to $500 \mathrm{mg}$ of each $\mathrm{H}_{2} \mathrm{O}_{2}$ treated soil (air-dry weight basis) in a 10-ml glass test tube and the test tube was shaken gently for $24 \mathrm{hr}$ to re-equilibrate the soil with water. Then a $2 \mathrm{ml}$ aliquot of each mepanipyrim solution was added to the test tube. The sample was shaken and centrifuged, and the supernatant was radioassayed in the same manner described above.

The $\mathrm{pH}$ of all supernatants was also measured.

\section{Calculations}

The concentration of mepanipyrim in the supernatant was calculated by assuming that all radioactivity in the supernatant was derived from mepanipyrim. The amount adsorbed was obtained as the difference between the amount in supernatant and the amount added to the centrifuge tube.

Adsorption isotherms were calculated using the logarithmic form of the Freundlich equation with the least square method:

$$
\log (x / m)=\log \left(K_{\mathrm{f}}\right)+(1 / n) \cdot \log \left(C_{\mathrm{e}}\right)
$$

where $x / m$ is the amount of mepanipyrim adsorbed on soil $(\mu \mathrm{g} / \mathrm{g}), C_{\mathrm{e}}$ is the concentration in the supernatant after the equilibration $(\mu \mathrm{g} / \mathrm{ml}), K_{\mathrm{f}}$ is the adsorption coefficient, and $1 / n$ is the slope.

$K_{\mathrm{f}, \mathrm{oc}}$, which is the normalized $K_{\mathrm{f}}$ value based on the soil organic carbon content, was obtained by the following equation:

$$
K_{\mathrm{f}, \mathrm{oc}}=\left(K_{\mathrm{f}} / O C \%\right) \cdot 100
$$

where $O C \%$ is the organic carbon content of soil.

Distribution coefficient was calculated to describe the desorption and $\mathrm{pH}$ effects on mepanipyrim adsorption by the following equation:

$$
K_{\mathrm{d}}=(x / m) / C_{\mathrm{e}}
$$

where $K_{\mathrm{d}}$ is the distribution coefficient. $K_{\mathrm{d}}$ values were also calculated with the equilibrium concentrations observed in desorption studies and the adsorption amounts obtained from the adsorption isotherms at the equilibrium concentrations. 


\section{RESULTS AND DISCUSSION}

\section{Adsorption Isotherms for the Soils}

Adsorption isotherms are shown in Fig. 2. $K_{\mathrm{f}}, 1 / n$, the coefficient of determination $\left(r^{2}\right), K_{\mathrm{f}, \mathrm{oc}}$, and $\mathrm{pH}$ of the supernatant are listed in Table 3.

The $r^{2}$ values, 1.000 for all soils tested, mean that the Freundlich equation well described the soil adsorption of mepanipyrim. The slopes $(1 / n)$ which were smaller than unity for all soils indicate that mepanipyrim adsorption was dependent on the initial mepanipyrim concentration in the solution and the proportion of molecules adsorbed decreased as the initial concentration increased. The $K_{\mathrm{f}}$ values for Nagano, Kikugawa, Ushiku, Koriyama, and Kume soils were 427, 22.4, 35.5, 14.5, and 12.9 , respectively. And the $K_{\mathrm{f}, \text { oc }}$ values were 3420,5210 , 1090,1340 , and 1630 , respectively.

Though the soil adsorption of chemicals is generally governed by the soil organic matter, $\mathrm{pH}$ can be influential in the case of ionizable compounds. It was reported that the adsorption of a weak base atrazine on geologic materials was correlated with $\mathrm{pH}$ more highly than with

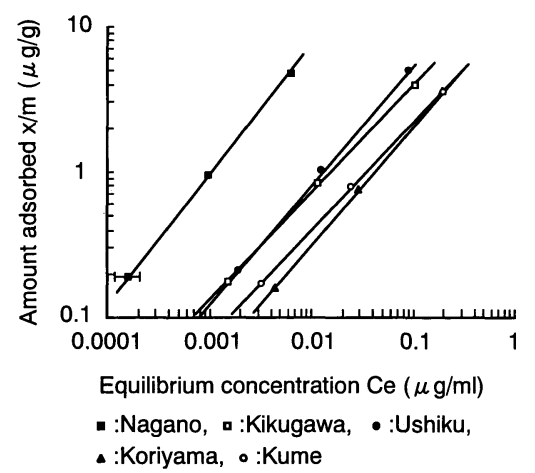

Fig. 2 Adsorption isotherms for the soils.

Error bars represent one standard deviation of the duplicate samples.
$O C \%{ }^{6)} \quad$ Also, it has been known that atrazine is adsorbed more at low $\mathrm{pH}$ than at high $\mathrm{pH}^{3-5)}$ Mepanipyrim is also a weak base compound having the $\mathrm{p} K$ a value of 2.9 and it was expected that its adsorption was influenced by $\mathrm{pH}$ as well as atrazine.

The $\mathrm{pH}$ values of equilibrium solutions were 6.4 for the Ushiku soil, 6.2 for Koriyama soil, and 5.0 for the other soils. The $K_{\mathrm{f}, \mathrm{oc}}$ values were greater for Kikugawa and Nagano soils having the lower $\mathrm{pH}$ value than those for Ushiku and Koriyama soils having the higher $\mathrm{pH}$ values. Especially Kikugawa soil having the lowest $O C \%$ gave the third greatest $K_{\mathrm{f}}$ value among the five soils. The $K_{\mathrm{f}, \mathrm{oc}}$ value for Kume soil, however, was relatively low in spite of its low $\mathrm{pH}$.

\section{Desorption from the Soils}

The $K_{\mathrm{d}}$ values obtained for desorption and those calculated from the adsorption isotherms at the equilibrium concentrations observed in the desorption studies are shown in Table 4.

The desorption $K_{\mathrm{d}}$ values were larger than those calculated. This suggests that mepanipyrim desorption from the soils is hysteretic and mepanipyrim once adsorbed on soils will be desorbed less than expected from the adsorption isotherm.

Table 4 Distribution coefficients $\left(K_{\mathrm{d}}\right)$ for the desorption of mepanipyrim from the soils and those calculated from the adsorption isotherms.

\begin{tabular}{lcc}
\hline Soil & $\begin{array}{c}K_{\mathrm{d}} \text { obtained from } \\
\text { desorption test }\end{array}$ & $\begin{array}{c}K_{\mathrm{d}} \text { calculated from } \\
\text { the isotherm }\end{array}$ \\
\hline Nagano & 1260 & 803 \\
Kikugawa & 57.4 & 44.4 \\
Ushiku & 79.5 & 59.3 \\
Koriyama & 26.9 & 20.8 \\
Kume & 30.5 & 22.1 \\
\hline
\end{tabular}

Table 3 Freundlich constants, coefficients of determination $\left(r^{2}\right)$, and normalized $K_{\mathrm{f}}$ based on organic carbon content $\left(K_{\mathrm{f}, \mathrm{cc}}\right)$ for the adsorption of mepanipyrim on five Japanese soils, and pH of supernatant.

\begin{tabular}{|c|c|c|c|c|c|c|}
\hline Soil $^{\text {a) }}$ & & $1 / n^{\mathrm{b})}$ & $K_{\mathrm{f}}^{\mathrm{c})}$ & $r^{2}$ & $K_{\mathrm{f}, \mathrm{oc}}$ & $\mathrm{pH}$ \\
\hline \multirow{2}{*}{ Nagano } & Original & $0.887(0.977-0.771)$ & $427(190-818)$ & 1.000 & 3420 & 5.0 \\
\hline & $\mathrm{H}_{2} \mathrm{O}_{2}$ & $0.852(0.795-0.909)$ & $48.7(38.1-62.2)$ & 0.998 & 5939 & 4.8 \\
\hline \multirow[t]{2}{*}{ Kikugawà } & Original & $0.747(0.723-0.774)$ & $22.4(20.0-25.5)$ & 1.000 & 5210 & 5.0 \\
\hline & $\mathrm{H}_{2} \mathrm{O}_{2}$ & $0.658(0.574-0.740)$ & $12.2(8.87-16.8)$ & 0.992 & 11100 & 5.7 \\
\hline \multirow[t]{2}{*}{ Ushiku } & Original & $0.817(0.790-0.846)$ & $35.5(31.6-40.9)$ & 1.000 & 1090 & 6.4 \\
\hline & $\mathrm{H}_{2} \mathrm{O}_{2}$ & $0.861(0.845-0.875)$ & $7.59(7.25-7.89)$ & 1.000 & 1310 & 6.0 \\
\hline \multirow[t]{2}{*}{ Koriyama } & Original & $0.832(0.821-0.845)$ & $14.5(13.7-15.1)$ & 1.000 & 1340 & 6.2 \\
\hline & $\mathrm{H}_{2} \mathrm{O}_{2}$ & $0.746(0.678-0.814)$ & $9.43(7.57-11.8)$ & 0.996 & 5240 & 5.9 \\
\hline \multirow[t]{2}{*}{ Kume } & Original & $0.756(0.734-0.779)$ & $12.9(11.9-14.2)$ & 1.000 & 1630 & 5.0 \\
\hline & $\mathrm{H}_{2} \mathrm{O}_{2}$ & $0.614(0.287-0.703)$ & $0.454(0.411-0.821)$ & 0.998 & 504 & 5.8 \\
\hline
\end{tabular}

a) The upper line for each soil shows the values for the original soil and the lower the values for the $\mathrm{H}_{2} \mathrm{O}_{2}$

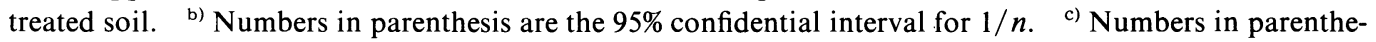
sis are the $95 \%$ confidential interval for $K_{\mathrm{f}}$. 


\section{Effect of $p H$ on the Adsorption of Mepanipyrim}

Fig. 3 shows the effect of $\mathrm{pH}$ of the equilibrium solution on the adsorption of mepanipyrim expressed in $K_{\mathrm{d}}$ value for Kikugawa and Koriyama soils. For both soils the $K_{\mathrm{d}}$ values increased as $\mathrm{pH}$ decreased, reaching the maximum at a $\mathrm{pH}$ value near the $\mathrm{p} K \mathrm{a}$ value of mepanipyrim. In the $\mathrm{pH}$ range below the $\mathrm{p} K \mathrm{a}$ value the $K_{\mathrm{d}}$ values decreased. This $\mathrm{pH}$ effect is analogous to that observed for the adsorption of s-triazine herbicides onto soil colloids, ${ }^{7), 8)}$ and aniline and toluidines onto montmorillonite. ${ }^{9)} \quad$ The increase in mepanipyrim adsorption with the decrease in $\mathrm{pH}$ would be attributed to the formation of the ionic bond between protonated mepanipyrim and the minus charge on the soil colloids in addition to other adsorption mechanisms. This increase in mepanipyrim adsorption got enhanced between $\mathrm{pH} 5$ to 6 for both soils. The percentage protonated of a weak base in a solution is given by the following equation ${ }^{10)}$ :

$$
\% \text { protonated }=100 /\left(1+10^{(\mathrm{pH}-\mathrm{pKa})}\right)
$$

Calculated from the equation, more than $99 \%$ of mepanipyrim molecule exists as a neutral form in the $\mathrm{pH}$ range above 5 so that the ionic bond doesn't seem to be involved in the increase in adsorption within this $\mathrm{pH}$ range. But the acidity at the soil colloid surface can account for this. In the vicinity of the soil colloid surface, cations accumulate to neutralize the minus charge on the soil colloid surface and the $\mathrm{pH}$ may be lower than that of equilibrium solution by as much as 2 $\mathrm{pH}$ units. ${ }^{\left.11),{ }^{12}\right)}$ On the basis of this $\mathrm{pH}$ difference mepanipyrim can be protonated and adsorbed through the ionic bond even when the $\mathrm{pH}$ of equilibrium solution is far above its $\mathrm{p} K$ a value. Assuming the difference of 2 $\mathrm{pH}$ units, $44.3 \%$ of mepanipyrim molecule in the acidic layer at the soil colloid surface can be protonated in Nagano, Kikugawa, and Kume soils, whose equilibrium solutions gave the $\mathrm{pH}$ of 5.0. On the other hand in

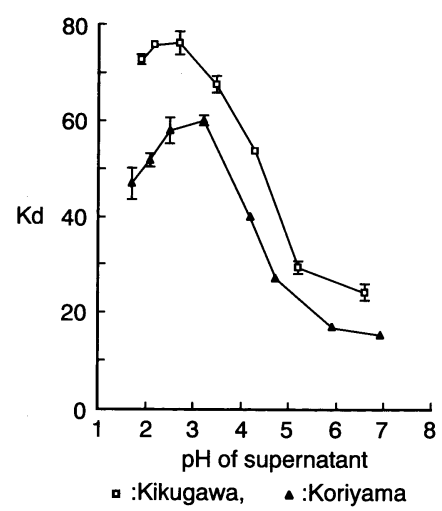

Fig. 3 Effect of $\mathrm{pH}$ on the $K_{\mathrm{d}}$ values of mepanipyrim adsorption onto Kikugawa and Koriyama soils. Error bars represent one standard deviation of the duplicate samples.
Koriyama and Ushiku soils giving the $\mathrm{pH}$ of 6.2 and 6.4, respectively, the percentages protonated were 4.7 and 3.1. Accordingly, the ionic bond is considered to be available in Nagano, Kikugawa, and Kume soils, while it is negligible in Koriyama and Ushiku soils.

In the $\mathrm{pH}$ range below the $\mathrm{p} K$ a value the competition with proton over the adsorption sites may decrease mepanipyrim adsorption as well as the case of the adsorption of s-triazines by clay minerals. ${ }^{8)}$

The mepanipyrim adsorption didn't change remarkably in the higher $\mathrm{pH}$ range above 5.2 for the Kikugawa soil and 5.9 for Koriyama soil. The reason is most likely that above a certain $\mathrm{pH}$ value all mepanipyrim molecules exist in a neutral form even in the vicinity of soil colloid surface and the adsorption of neutral molecule is little affected by $\mathrm{pH}^{13)}$

Consequently, it is confirmed that the $\mathrm{pH}$ of equilibrium solution controls the affinity of the soils for mepanipyrim. The difference of the affinity between Kikugawa and Koriyama soils may be partly attributed to the $\mathrm{pH}$ difference between both soils.

\section{Adsorption Isotherms and Effect of $p H$ on the} Adsorption for the $\mathrm{H}_{2} \mathrm{O}_{2}$ Treated Soils

$K_{\mathrm{f}}, 1 / n, r^{2}, K_{\mathrm{f}, \mathrm{oc}}$, and $\mathrm{pH}$ of supernatants for the $\mathrm{H}_{2} \mathrm{O}_{2}$ treated soils are shown in Table 3 and the effect of $\mathrm{pH}$ on the adsorption for the $\mathrm{H}_{2} \mathrm{O}_{2}$ treated soil expressed in $K_{\mathrm{d}}$ value is shown in Fig. 4.

The $K_{\mathrm{f}}$ values for Nagano, Kikugawa, Ushiku, Koriyama, and Kume $\mathrm{H}_{2} \mathrm{O}_{2}$ treated soils were 48.7, 12.2, 7.59, 9.43, and 0.454, respectively. After the $\mathrm{H}_{2} \mathrm{O}_{2}$ treatment $K_{\mathrm{f}}$ values for Nagano, Ushiku, and Kume soils decreased remarkably to $11.4,21.4$, and $3.5 \%$ of those for their respective original soils, while the decrease in $K_{\mathrm{f}}$ values for Kikugawa and Koriyama soils were less remarkable

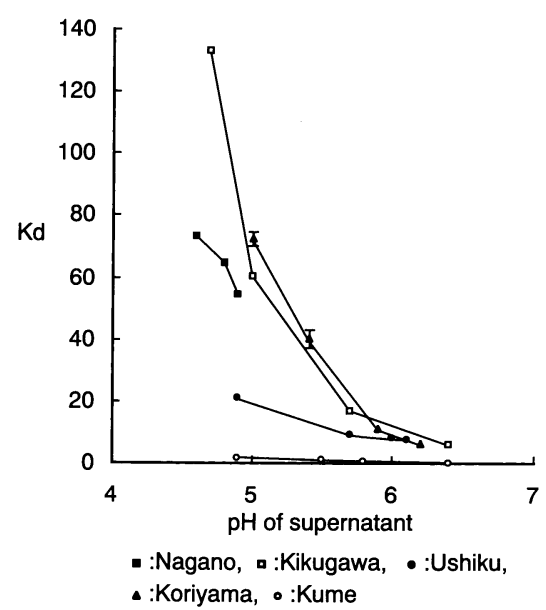

Fig. 4 Effect of $\mathrm{pH}$ on the $K_{\mathrm{d}}$ values of mepanipyrim adsorption onto the $\mathrm{H}_{2} \mathrm{O}_{2}$ treated soils.

Error bars represent one standard deviation of the duplicate samples. 
giving the $K_{\mathrm{f}}$ values of 54.5 and $65.0 \%$ of those for their respective original soils.

Similar to the $\mathrm{pH}$ effect for Kikugawa and Koriyama original soils in the $\mathrm{pH}$ range above the $\mathrm{p} K$ a value, the adsorption increased while the $\mathrm{pH}$ value decreased for all $\mathrm{H}_{2} \mathrm{O}_{2}$ treated soils. The $\mathrm{pH}$ effect was remarkable for Kikugawa, Koriyama, and Nagano soils, but not so for Ushiku and Kume soils.

\section{Corrected $\mathrm{K}_{\mathrm{f}}$ Values for the $\mathrm{H}_{2} \mathrm{O}_{2}$ Treated Soils and Discussion on the Adsorption Capacities}

Since the $\mathrm{H}_{2} \mathrm{O}_{2}$ treatment induced some changes in the $\mathrm{pH}$ values of the supernatants as shown in Table 3, corrected $K_{\mathrm{f}}$ values for the $\mathrm{H}_{2} \mathrm{O}_{2}$ treated soils were calculated at the $\mathrm{pH}$ for their respective original soils to compare directly with the $K_{\mathrm{f}}$ values of the original soils. Using the $K_{\mathrm{d}}$ value at the $\mathrm{pH}$ of each original soil obtained from the Fig. 4 by interpolation or extrapolation, the amount adsorbed and the supernatant concentration were calculated with the initial concentration of $1.02 \mu \mathrm{g} / \mathrm{ml}$ and then the corrected $K_{\mathrm{f}}$ value was obtained from the Freundlich equation :

$$
x / m=K_{\mathrm{f}} \cdot C_{\mathrm{e}}^{1 / n}
$$

It was assumed that the $1 / n$ value was equal to that of the isotherm for each $\mathrm{H}_{2} \mathrm{O}_{2}$ treated soil shown in Table 3 .

The corrected $K_{\mathrm{f}}$ values for Nagano, Kikugawa, Ushi$\mathrm{ku}$, Koriyama, and $\mathrm{Kume} \mathrm{H}_{2} \mathrm{O}_{2}$ treated soils were 33.7, $29.4,4.89,5.61$, and 1.34, respectively. From the comparison between the corrected $K_{\mathrm{f}}$ values and $K_{\mathrm{f}}$ values for the original soils, in the Nagano, Ushiku, and Kume soils, whose $K_{\mathrm{f}}$ values decreased remarkably by the $\mathrm{H}_{2} \mathrm{O}_{2}$ treatment, the soil organic matter is considered to be the main adsorbent in mepanipyrim adsorption in their original soils. The $K_{\mathrm{f}}$ value for Koriyama soil also decreased but not remarkably. Therefore, both the organic matter and mineral constituents may play the major roles in the original soil. In the case of Kikugawa soil, the $K_{\mathrm{f}}$ value increased after the $\mathrm{H}_{2} \mathrm{O}_{2}$ treatment. This indicates the importance of soil mineral constituents in original Kikugawa soil on mepanipyrim adsorption.

Around $\mathrm{pH} 5$ the adsorption capacities for Nagano, Kikugawa, and Koriyama $\mathrm{H}_{2} \mathrm{O}_{2}$ treated soils seemed almost the same. On the other hand Ushiku and Kume $\mathrm{H}_{2} \mathrm{O}_{2}$ treated soils showed relatively low adsorption capacities. Especially the adsorption capacity for the Kume $\mathrm{H}_{2} \mathrm{O}_{2}$ treated soil was the lowest over the $\mathrm{pH}$ range tested. It can be considered that the high affinity of the Kikugawa original soil in spite of its low $O C \%$ is due to the contribution of the high adsorption capacity of its mineral constituents besides its low $\mathrm{pH}$, and the low affinity of the Kume soil having the lower $\mathrm{pH}$ value is attributed to the low adsorption capacity of mineral constituents in addition to its low $O C \%$.
The difference in the adsorption capacities of the $\mathrm{H}_{2} \mathrm{O}_{2}$ treated soils may be due to the difference in the main clay minerals contained in the soils. Kikugawa, and Koriyama soils whose $\mathrm{H}_{2} \mathrm{O}_{2}$ treated soils had high adsorption capacities contained 2:1 type clay minerals, ilite or vermiculite. On the other hand the main clay mineral in the Kume soil was halloysite which is a $1: 1$ type clay mineral. Because the $2: 1$ type clay minerals generally have a large surface area and a high layer charge independent of $\mathrm{pH}$, compared to the $1: 1$ type clay minerals, ${ }^{14)}$ the $2: 1$ type clay minerals can adsorb protonated mepanipyrim more strongly than the $1: 1$ type clay minerals. Allophane, which was the main clay mineral in the Ushiku soil, has minus charge dependent on $\mathrm{pH}$ and its CEC decreases rapidly as $\mathrm{pH}$ decreases. ${ }^{15)}$ Therefore, it doesn't seem to work as an effective adsorbent for a weak base compound which becomes protonated as the $\mathrm{pH}$ decreases. This is because the $\mathrm{pH}$ change affected little on mepanipyrim adsorption on Ushiku $\mathrm{H}_{2} \mathrm{O}_{2}$ treated soil. Remaining organic carbon in Nagano $\mathrm{H}_{2} \mathrm{O}_{2}$ treated soil may contribute to its high adsorption capacity. However, the vermiculite contained in Nagano soil is also considered to be significant for its adsorption capacity.

\section{ACKNOWLEDGMENTS}

The authors wish to thank K-I Chemical Research Institute Co., Ltd. for providing the data of $\mathrm{p} K \mathrm{a}$ and authentic compound of mepanipyrim and appreciate encouragement and helpful advice given by Dr. K. Ishikawa.

\section{REFERENCES}

1) S. Hayashi, S. Maeno, T. Kimoto \& T. Nagata: J. Pesticide Sci. 22, 165 (1997)

2) "The Pesticide Manual 11th edition," ed. by C.D.S. Tomlin, p. 784,1997

3) G. R. Harris \& K. Hurle: Weed Res. 19, 343 (1979)

4) S. A. Clay \& W. C. Koskinen: Weed Sci. 38, 262 (1990)

5) M. D. McGlamery \& F. W. Slife: Weeds 14, 237 (1966)

6) W. R. Roy \& I. G. Krapac: J. Environ. Qual. 23, 549 (1994)

7) J. B. Weber, S. B. Weed \& T. M. Ward: Weed Sci. 17, 417 (1969)

8) J. B. Weber: Residue Rev. 32, 93 (1970)

9) M. E. Essington: Soil Sci. 158, 181 (1994)

10) A. Albert \& E. P. Serjeant: "Ionization Constants of Acids and Bases," Metheun \& Co., Ltd., London, p.14, 1962

11) M.H.B. Hayes: Residue Rev. 32, 131 (1970)

12) H. L. Bohn, B. L. McNeal \& G. A. O'Conner: "Soil Chemistry. 2nd ed.," John Wiley \& Sons, New York, p. 219, 1985

13) D. J. Arnold \& G. G. Briggs: "Environmental Fate of Pesticides," ed. by D. H. Hutson \& T. R. Roberts, Vol. 7, John Wiley \& Sons Ltd., Chichester, p. 104, 1990

14) S. U. Kahn: "Pesticides in the Soil Environment," Elsevier Scientific Publishing Co., New York, pp. 30-32, 1980

15) S.Shoji: "Shin Dojogaku," Asakura Shoten, Tokyo, pp. 7576, 1984 (in Japanese) 


\section{要 約}

\section{殺菌剤メパニピリムの土壤吸着と光の機構}

永井雄太郎, 榛葉香代子, 遊佐義男, 箭木 昭

${ }^{14} \mathrm{C}$ 標識メパニピリムを用い, その土㙵吸着性および吸 着特性を 5 種類の畑土壌について調べた.

3 段階の濃度で実施した吸脱着試験の結果，メパニピリ ムの土壌吸着はフロイントリッヒの吸着等温式によく適合 した. 吸着係数 $K_{\mathrm{f}}$ は 12.9 から 427 であり, $1 / n$ はすべての 土壌で 1 より小さった。また， $K_{\mathrm{f}}$ を有機炭素含量で割り
算出した $K_{\mathrm{f}, \mathrm{oc}}$ は， 1090 から 5210 であった，脱着において ヒステリシスが認められた。メパニピリムの吸着は $\mathrm{pH}$ 依 存性であり, $\mathrm{pH}$ の低下に伴い増加し, $\mathrm{p} K \mathrm{a}(2.9)$ 付近で最 大となった。この $\mathrm{pH}$ 依存性には, プロトネーションしたメ パニピリムと土壤コロイドの負電荷との間のイオン結合が 関与していると推察された。過酸化水素により土壌有機物 を分解すると, 全ての土㙵で $K_{\mathrm{f}}$ 值が減少した. $\mathrm{p} K \mathrm{a}$ 以上の $\mathrm{pH}$ において, 過酸化水素処理した土壌への吸着も, $\mathrm{pH} の$ 低下にともない増加した。 